\title{
Korelasi antara Lama Studi dan Tingkat Kecemasan Mahasiswa
}

\section{Mohammad Bakhriansyah}

Fakultas Kedokteran Universitas Lambung Mangkurat Banjarbaru

Korespondensi: bakhriansyah@gmail.com

\begin{abstract}
Background: Medical students face many changes when they entered higher education. These changes of learning occurred in competency based curriculum compared to at high school learning such as approach of problem based learning and skills lab. The changes create anxiety for them. However, theoretically, anxiety decreases with longer exposure.

Objectives: The aims of this study were to find out the different of students' anxiety status when they were at semester 1 and 2. It was also to find out the correlation between the length of study and anxiety level.

Methods: This was a descriptive study involving UNLAM medical students. 73 students were involved in this study at semester 1 and 88 students were involved in semester 2. Anxiety status was defined by using ADS questionnaire. Afterward the data were analysed using Chi-square and Coefficient of Correlation at $95 \%$ level of confident.

Results: There was 20 students (37.4\%) experiencing anxiety at semester 1 and 11 students (12.5\%) at semester 2, the different was statistically different $(p=0.000$ ). The correlation between the length of study and anxiety level was also statistically different $(p=0.008)$, with very weak negative correlation $(p=0.188)$.

Conclusion: There is a significant difference of anxiety level among medical students at semester 1 and 2. There is also significantly negative correlation between anxiety level and the length of study on medical students.
\end{abstract}

Keywords: anxiety, length of study, competency based curriculum

\section{Abstrak}

Latar Belakang: Mahasiswa kedokteran menghadapi berbagai perubahan ketika memasuki jenjang pendidikan tinggi. Perubahan ini adalah perubahan pada kurikulum berbasis kompetensi dibandingkan dengan waktu mereka masih di sekolah menengah atas, seperti adanya pembelajaran berdasar masalah dan skills lab. Perubahan ini dapat memunculkan kecemasan, meski secara teori, semakin lama mereka berada pada sistem ini, semakin rendah kecemasannya.

Tujuan: Penelitian ini bertujuan untuk mengetahui perbedaan status kecemasan ketika mahasiswa berada di semester 1 dan 2, serta untuk mengetahui korelasi antara lama studi dengan status kecemasan pada mahasiswa pada kurikulum berbasis kompetensi.

Metode: Penelitian ini merupakan penelitian deskriptif terhadap 91 mahasiswa kedokteran angkatan 2010. Sebanyak 73 mahasiswa terlibat pada penelitian di semester 1, sedangkan di semester 2 sebanyak 88 orang. Status kecemasan ditentukan dengan menggunakan kuesioner ADS. Data selanjutnya dianalisis menggunakan uji Chi-square dan Koefisien Korelasi dengan tingkat kepercayaan 95\%.

Hasil: Terdapat 20 mahasiswa (37,4\%) yang mengalami kecemasan di semester 1 dan 11 mahasiswa (12,5\%) di semester 2. Angka ini menunjukkan perbedaan yang bermakna $(p=0,000)$. Korelasi antara lama studi dengan status kecemasan secara statistik juga berbeda $(p=0,008)$, tetapi korelasinya sangat lemah $(p=0,188)$ dan arahnya negatif.

Kesimpulan: Terdapat perbedaan status kecemasan yang bermakna antara mahasiswa ketika berada di semester 1 dan semester 2 dan terdapat korelasi yang sangat lemah antara lama studi dengan status kecemasan.

Kata Kunci: kecemasan, lama studi, Kurikulum Berbasis Kompetensi

Korespondensi: bakhriansyah@gmail.com 


\section{PENDAHULUAN}

Berdasarkan Undang-Undang Republik Indonesia Nomor 20 Tahun 2003 tentang Sistem Pendidikan Nasional, model kurikulum yang diterapkan di semua jenjang pendidikan di Indonesia adalah Kurikulum Berbasis Kompetensi (KBK). KBK dimaksudkan untuk dapat mencapai keunggulan bangsa, sehingga mampu bersaing di dunia. ${ }^{1}$

KBK merupakan seperangkat rencana dan pengaturan tentang kompetensi dan hasil belajar yang harus dicapai mahasiswa, prosedur penilaian, kegiatan belajar mengajar, dan pemberdayaan sumber daya pendidikan. KBK berorientasi pada pencapaian hasil yang dirumuskan dalam bentuk kompetensi. ${ }^{1,2}$

Salah satu perguruan tinggi di Indonesia yang telah menerapkan sistem pendidikan KBK adalah Fakultas Kedokteran Universitas Lambung Mangkurat (FK UNLAM). FK UNLAM telah menerapkan kurikulum ini sejak tahun 2008. ${ }^{3}$

Perubahan paradigma pendidikan kedokteran yang digunakan oleh FK UNLAM dari pembelajaran yang berpusat pada dosen (teacher-centred learning) ke arah pembelajaran yang berpusat pada mahasiswa (studentcentred learning) menjadikan mahasiswa dituntut untuk mengubah cara belajarnya, karena adanya perbedaan yang signifikan dengan metode yang diterapkan pada masa Sekolah Menengah Atas (SMA). ${ }^{4}$ Perbedaan signifikan itu adalah metode pengajaran dan pembelajaran yang digunakan pada sistem KBK di Fakultas Kedokteran yang menggunakan perkuliahan, tutorial, diskusi pleno, kuliah pakar, belajar mandiri, praktikum, skills lab, patient based learningsedangkan pada saat SMA hanya menggunakan diskusi kelompok. ${ }^{4,5}$

Salah satu model pembelajaran yang diterapkan pada sistem KBK adalah Problem based Learning (PBL). PBL adalah model pembelajaran yang melibatkan siswa untuk memecahkan suatu masalah melalui tahap-tahap metode ilmiah sehingga siswa dapat mempelajari pengetahuan yang berhubungan dengan masalah tersebut dan sekaligus memiliki keterampilan untuk memecahkan masalah.

Sistem pembelajaran dengan menggunakan PBL akan memicu munculnya kecemasan. Hal ini dapat terjadi karena arahan dalam belajar, tidak efektifnya sistem pembelajaran dan informasi yang kurang akurat, kelompok diskusi yang kurang dinamis dan tidak terdapat sikap saling membantu antar peserta menjadi pemicu dalam timbulnya kecemasan. ${ }^{7}$ Pembelajaran dengan sistem PBL dapat menjadi sumber dari ketegangan, frustasi, kelemahan dan kecemasan bagi siswa. ${ }^{8}$ Sebuah penelitian mengungkapkan bahwa pada subyek penelitian yang mendapatkan treatment paparan kecemasan lebih lama, akan mengalami penurunan prevalensi kecemasan. ${ }^{9}$

Berdasarkan uraian pada latar belakang masalah di atas, dapat dirumuskan permasalahan penelitian apakah terdapat perbedaan prevalensi kecemasan pada mahasiswa Program Studi Pendidikan Dokter FK UNLAM angkatan 2010 pada KBK di semester 1 dan semester 2 proses pembelajaran dan bagaimana korelasi antara lama studi dan kejadian kecemasan?

\section{METODE PENELITIAN}

Penelitian ini merupakan penelitian deskriptif analitik dengan pendekatan historical cohort pada responden seluruh mahasiswa PSPD FK UNLAM angkatan 2010/ 2011. Angkatan ini dipilih karena merupakan angkatan paling baru di lingkungan FK UNLAM dan mereka berada pada masa penyesuaian diri dengan sistem pembelajaran baru di lingkungan pendidikan tinggi. Responden penelitian diberikan kuesioner Anxiety Depression and Vulnerability Rating Scale (ADS). Data diambil sewaktu mereka berada pada semester 1 dan semester 2 . Kuesioner ADS digunakan untuk menilai adanya kecemasan pada mahasiswa tersebut. Apabila nilai yang diperoleh e" 9, maka mahasiswa dinyatakan mengalami kecemasan. Sebelum mahasiswa mengisi kuesioner tersebut, mahasiswa diminta mengisi lembar informed consent sebagai bukti kesediaan menjadi subyek di dalam penelitian ini. Data selanjutnya dianalisis menggunakan uji statistik Chi-square test dan koefisien korelasi dengan tingkat kepercayaan 95\%.

\section{HASIL PENELITIAN}

Saat dilakukan penelitian di semester 1, dari 91 mahasiswa ada 73 mahasiswa yang bersedia menjadi responden, sedangkan pada saat mereka berada di semester 2 sebanyak 88 orang yang mengisi kuesioner ADS dari 91 mahasiswa. Pada semester 1 ditemukan ada 20 orang $(37,4 \%)$ mahasiswa yang mengalami kecemasan, sedangkan pada semester 2 angka ini menurun menjadi 11 orang mahasiswa $(12,5 \%)$. Perubahan ini lebih jelas ditunjukkan pada Gambar 1. 


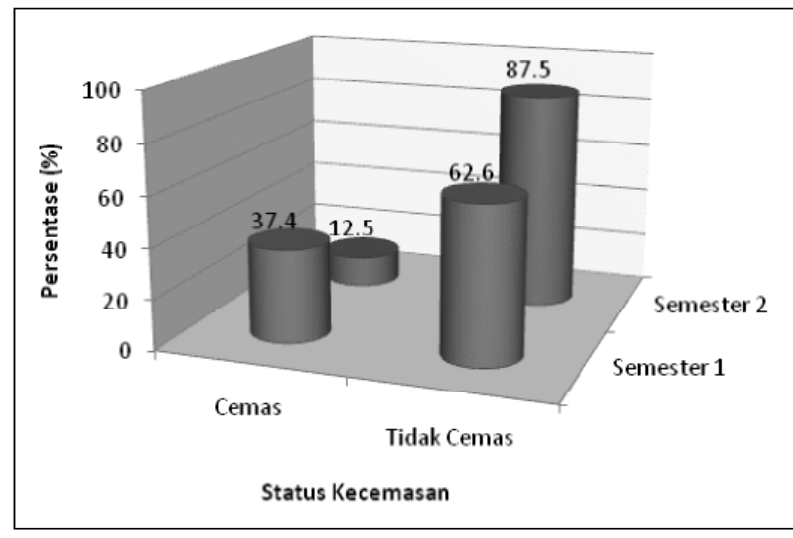

Gambar 1. Grafik persentase (\%) perubahan kecemasan pada mahasiswa program studi pendidikan dokter FK UNLAM semester I dan II

Penelitian di PSPD FK UNLAM ini melibatkan ratarata 80,5 mahasiswa untuk masing-masing tahap. Pada penelitian tahap I di semester 1 terdapat drop out rate sebesar 20,00\%, sedangkan pada penelitian tahap II di semester 2 drop out rate berkurang menjadi 3,30\%.

Untuk menilai perbedaan status kecemasan di semester 1 dan 2 pada mahasiswa PSPD FK UNLAM angkatan 2010 dan korelasi antara lama studi dengan status kecemasan pada mahasiswa tersebut digunakan berturutturut uji Chi-square dan Korelasi Pearson dengan tingkat kepercayaan 95\%. Berdasarkan uji Chi-square terlihat bahwa nilai $\mathrm{p}=0,000$. Hal ini menunjukkan bahwa terdapat perbedaan yang bermakna pada status kecemasan mahasiswa angkatan 2010 PSPD FK UNLAM di semester 1 dan 2. Pada uji Koefisien Korelasi terlihat bahwa terdapat korelasi yang bermakna antara lama studi dengan status kecemasan $(p=0,008)$, tetapi korelasi yang muncul bersifat sangat lemah $(\mathrm{r}=0,188)$ dengan arah korelasi yang negatif (-). Artinya, semakin lama mahasiswa menempuh masa studi, maka semakin sedikit yang mengalami kecemasan. Data hasil pengujian statistik ini lebih jelas ditunjukkan pada Tabel 1 di bawah ini.

Tabel 1. Hasil analisis statistik kecemasan pada mahasiswa PSPD FK UNLAM angkatan 2010 di semester 1 dan 2

\begin{tabular}{lcc}
\multicolumn{1}{c}{ Analisis statistik } & $\mathrm{p}$ & Interpretasi \\
\hline Chisquare & 0,000 & Berbeda bermakna \\
\hline Koefisien korelasi (Pearson) & 0,008 & Korelasi bermakna \\
\hline
\end{tabular}

\section{PEMBAHASAN}

Pendidikan dokter dianggap menjadi sumber kecemasan dan stres. Stres dan kecemasan meningkat secara bermakna pada mahasiswa terutama di tahun pertama pendidikan. ${ }^{10}$ Selain masalah interpersonal yang dialami, masalah kesehatan mental seperti kecemasan, stres, depresi dan gangguan afektif sementara sangat mempengaruhi prestasi akademik mahasiswa. ${ }^{11}$

Pada penelitian ini terdapat $14(37,4 \%)$ dari 73 mahasiswa yang mengalami kecemasan di semester I. Prevalensi ini mengalami penurunan pada semester II menjadi 11 (12,5\%) dari 88 mahasiswa. Paparan yang lebih lama terhadap sumber kecemasan akan menurunkan tingkat kecemasan yang dialami subyek penelitian. ${ }^{9}$ Hal tersebut sesuai dengan temuan pada penelitian ini. Jadi dapat diasumsikan bahwa mahasiswa memiliki kemampuan adaptasi yang baik terhadap perubahan metode belajar yang dijalankan di PSPD FK UNLAM. Kecemasan merupakan reaksi kejiwaan yang muncul akibat adanya permasalahan. ${ }^{12}$ Gejala kecemasan yang sering dialami oleh seseorang yaitu memandang diri rendah, sulit untuk merasa senang atau pemurung, mudah menangis, tidak ada kepercayaan diri, mudah tegang dan gelisah, menghindari hal-hal yang tidak menyenangkan, jantung sering berdebar-debar, mulut terasa kering, berkeringat dan merasa takut mati. ${ }^{13}$

Berbagai sumber kecemasan yang dialami mahasiswa fakultas kedokteran dapat muncul dari berbagai metode pembelajaran. Sistem pembelajaran dengan menggunakan PBL akan menguatkan munculnya kecemasan karena kurangnya arahan dalam belajar, tidak efektifnya sistem pembelajaran dan informasi yang kurang akurat, kelompok diskusi yang kurang dinamis dan tidak terdapat sikap saling membantu antar peserta juga menjadi pemicu dalam timbulnya kecemasan.? Pembelajaran dengan sistem PBL dapat menjadi sumber dari ketegangan, frustasi, kelemahan dan kecemasan bagi mahasiswa. ${ }^{8}$ Kemudian siswa yang mengikuti sistem PBL memiliki tingkat yang lebih tinggi terhadap orientasi tujuan intrinsik, nilai tugas, menggunakan strategi elaborasi pembelajaran, berpikir kritis, metakognitif regulasi diri, pengaturan usaha, dan rekan belajar dibandingkan dengan siswa lain. Sebaliknya, tingkat kecemasan yang lebih tinggi didapatkan pada pelajaran tersebut. $^{14}$ 
Hasil ini selaras dengan beberapa penelitian yang telah dilakukan di beberapa negara, seperti di Malaysia, Pakistan, Arab Saudi, dan Republik Macedonia. Depresi dan kecemasan adalah hal yang lazim ditemukan pada mahasiswa fakultas kedokteran dari negara-negara Arab sama halnya dengan mahasiswa kedokteran di negara lain. ${ }^{15}$ Pada penelitian di Malaysia, 41,9\% dari 396 mahasiswa pada fakultas kedokteran satu universitas lokal mengalami depresi. ${ }^{16}$ Di Nishtar Medical College Multan Pakistan, dari 482 mahasiswa ditemukan ada 43,89\% mahasiswa yang mengalami kecemasan dan depresi. ${ }^{17}$ Sementara itu, dari 142 mahasiswa di Medical College Karachi, 70\% mengalami depresi dan kecemasan. ${ }^{18}$ Di College of Medicine, Qassim University Saudi Arabia, terdapat rata-rata 55\% dari 393 mahasiswa yang mengalami kecemasan dan depresi. Meskipun demikian belum ditemukan adanya ide untuk bunuh diri. ${ }^{19}$ Sementara itu pada mahasiswa pendidikan dokter di sekolah swasta di Malaysia, dari 252 mahasiswa yang terlibat penelitian, terdapat 46,2\% mahasiswa yang mengalami gangguan emosi. ${ }^{20}$ Dari 354 mahasiswa FK di Republik Macedonia yang terlibat penelitian, ditemukan ada $10,4 \%$ yang mengalami depresi dan $65,5 \%$ yang mengalami kecemasan. Bahkan, pada penelitian ini mahasiswa ditemukan menyalahgunakan obat dan zat aditif, seperti alkohol, rokok, dan obat penenang. Penyalahgunaan alkohol paling banyak ditemukan, sedangkan prevalensi merokok ditemukan pada $25 \%$ mahasiswa, dan penggunaan obat penenang golongan benzodiazepine sebesar $13,1 \%$ mahasiswa. ${ }^{21}$

Hasil penelitian ini juga sesuai dengan penelitian yang telah dilakukan oleh Zaid et al yang menyatakan bahwa gangguan emosional yang terjadi pada mahasiswa kedokteran berhubungan dengan lama studi, tekanan yang dihadapi sebelum ujian, dan tidak memiliki hubungan cinta. Namun, hasil penelitian ini bertentangan dengan penelitian yang dilakukan oleh Inam dan Jadoon et al, yang menyatakan bahwa tidak ada pola tertentu pada status kecemasan dan depresi pada mahasiswa ditinjau dari lama studi. ${ }^{17,} 19$

Sementara itu, berdasarkan analisis statistik korelasi antara lama studi dengan status kecemasan pada penelitian ini adalah sangat lemah. Hal ini mengindikasikan bahwa banyak faktor lain yang lebih berpengaruh terhadap status kecemasan yang dialami oleh mahasiswa. Penyebab gangguan emosional baik berupa depresi, kecemasan, dan stres pada mahasiswa kedokteran bersumber dari:
1. Penyesuaian diri dengan lingkungan sekolah. Mahasiswa tahun pertama menghadapi masalahmasalah seperti lepas dari keluarga dan teman serta adaptasi dengan lingkungan belajar yang baru yang penuh tuntutan. Selain itu faktor lain yang berperan adalah diseksi cadaver, beban kuliah yang berat dan kekhawatiran terhadap performa akademiknya. Usaha untuk menguasai informasi yang luas dan berada di kelompok yang memiliki motivasi dan tingkat kecerdasan yang sama dapat mengintimidasi mahasiswa.

2. Konflik etik. Interaksi interpersonal antara mahasiswa dengan dosen dapat mempengaruhi mahasiswa. Sebagian besar interaksi ini terjadi pada suasana yang informal. Kurikulum informal ini menjadi pesan yang baik tentang nilai profesionalisme, karakter dan norma. Sayangnya depresi, dan stres merupakan hal yang lazim pada supervisor sehingga dapat menjadi sikap yang tidak sesuai dengan etik dan berlawanan dengan kurikulum formal.

3. Paparan terhadap kematian dan penderitaan umat manusia.

4. Pelecehan oleh mahasiswa atau staf lain. Korban pelecehan banyak terjadi pada wanita terutama pada fase profesi, sedangkan yang paling sering melakukan pelecehan adalah perawat dan staf. Wujud pelecehan yang sering terjadi adalah pelecehan secara verbal.

5. Masalah pribadi. Masalah pribadi ini meliputi kematian anggota keluarga, cedera atau sakit, atau perubahan status kesehatan dari keluarga. Kondisi ini sangat mempengaruhi kualitas hidup mahasiswa dan perkembangan sikap professional mereka. Sebaliknya, pernikahan dapat menjadi pelindung terhadap stres.

6. Hutang untuk pendidikan. Meski belum ada penelitian khusus hubungan kesehatan mental mahasiswa fakultas kedokteran dengan efek hutang, masalah finansial merupakan sumber stres utama.22

Hal ini bertentangan dengan hasil penelitian yang dilakukan oleh Zaid et al. Mereka tidak menemukan adanya perbedaan yang bermakna secara statistik antara riwayat gangguan medis sebelumnya, hubungan dengan orangtua, saudara, teman kuliah dan dosen terhadap gangguan emosional. Tidak juga ditemukan hubungan dengan keragaman etnis, jenis kelamin, usia, jumlah ujian, dan hasil ujian. ${ }^{20}$ 
Beberapa hal dapat dilakukan baik oleh mahasiswa maupun oleh dosen untuk menurunkan stres. Menciptakan lingkungan pembelajaran yang mendukung, mengidentifikasi dan membantu mahasiswa untuk dapat bertahan dengan berbagai kondisi yang mengganggu kejiwaan, mengajarkan keterampilan untuk penanganan stres dan memicu kesadaran diri akan adanya gangguan, serta membantu mahasiswa untuk meningkatkan kesehatan individu merupakan contoh hal-hal yang dapat mengurangi stress. ${ }^{22}$

\section{KESIMPULAN}

Berdasarkan penelitian yang sudah dilakukan, maka dapat diambil kesimpulan sebagai berikut:

1. Kecemasan dialami oleh mahasiswa UNLAM dengan prevalensi menurun pada semester yang lebih tinggi.

2. Terdapat perbedaan yang bermakna $(\mathrm{p}=0,000)$ status kecemasan pada mahasiswa PSPD FK UNLAM angkatan 2010 saat semester 1 dan semester 2 .

3. Terdapat korelasi yang bermakna $(p=0,008)$ antara lama studi dengan status kecemasan pada mahasiswa PSPD FK UNLAM angkatan 2010, dengan arah korelasi negatif dan keeratan hubungan yang sangat lemah $(\mathrm{r}=0,188)$.

\section{DAFTAR PUSTAKA}

1. Anonim. Kurikulum berbasis kompetensi. Jakarta: Depdiknas, 2002.

2. Sidi ID. Strategi pendidikan nasional. Malang: IKIP Malang, 2001.

3. Anonim. Buku panduan fakultas kedokteran. Banjarbaru: FK UNLAM, 2008.

4. Kurniawan B. Studi deksriptif mengenai kemandirian mahasiswa kedokteran UKM. FK UKM 2007; [online]. Diunduh di: URL: http: //www.indoskripsi.com. Diakses 5 Maret 2010.

5. Anonim. Standar kompetensi dokter. Jakarta: Konsil Kedokteran Indonesia, 2006

6. Smith T, Renk K. Predictors of academic-related stress in college students: an examination of coping, social support, parenting, and anxiety. Naspa Journal. 2007;44(3):405-31.

7. Treloar C, McCall N, Rolfe I, Pearson SA, Garvey G, Heatcote A. Factors affecting progress of Australian and international students in a problem-based learning medical course. Med Ed. 2000;34:708-15.

8. Wolf TM, Scurria PL, Webster MG. A four-year study of anxiety, depression, loneliness, social support and perceived mistreatment in medical students. J Health Psychol. 2001;3(1):125-36.

9. Parsons T, Rizzo AA. Affective outcomes of virtual reality exposure therapy for anxiety and specific phobias: a meta-analysis. Journal of Behavior Therapy and Experimental Psychiatry. 2008;39:250-261.

10. Tooth D, Tonge K, McManus IC. Anxiety and study methods in pre clinical students: causal relation to examination performance. Med Ed. 1989;23:416-21.

11. Kernan WD, Wheat ME. Linking learning and health: a pilot study of medical students' perceptions of the academic impact of various health issues. Academic Psychiatry. 2008;32:61-4.

12. Trismiati. Perbedaan tingkat kecemasan antara pria dan wanita akseptor kontrasepsi mantap di RSUP Dr. Sardjito Yogyakarta. Jurnal Psyche. 2004;1:1.

13. Mary A Bell, Paula S Smith, James J Brokaw dan Herbert E Cushing. A family day program enhances knowledge about medical school culture and necessary supports. BMC Med Ed. 2004;4(3):1-3.

14. Sungur S, Tekkaya C, and Geban O. Improving achievement through problem based learning. Journal of Biological Education. 2006;40:155-60.

15. Elzubeir MA, Elzubeir KE, and Magzoub ME. Stress and coping strategies among Arab medical students: towards a research agenda. Educ for Health. 2010;23(1):1-16

16. Sherina MS, Rampal L, and Kaneson N. Psychological stress among undergraduate medical students. Med J Malaysia. 2004;59(2):207-11.

17. Jadoon NA, Yaqoob R, Raza A, Shehvad MA, and Choudry ZS. Anxiety and depression among medical students: a cross sectional study. J Pak Med Assoc. 2010;60:699-702.

18. Khan MS, Mahmood S, Badshah A, Ali SU, and Jamal Y. Prevalence of depression, anxiety and their associated factors among medical students in Karachi, Pakistan. JPMA. 2006;56:583-6.

19. Inam SNB. Anxiety and depression among medical students of a medical college in Saudi Arabia. Int. J. Health Sciences. 2007; 1(2):295-300.

20. Zaid ZA, Chan SC, and Ho JJ. Emotional disorders among medical students in a Malaysian private medical school. Singapore Med J. 2007;48(10):895-9.

21. Mancevska S, Bozinovska L, Tecce J, PluncevikGligoroska J, and Sivevska-Smilevska E. Depression, anxiety and substance abuse in medical student in the Republic of Macedonia. Bratisl Lek Listy. 2008;109(12);568-72.

22. Dyrbye LN, Thomas MS, and Shanafelt TD. Medical student distress: causes, consequences, and proposed solutions. Mayo Clinic Proc. 2005;80(12):1613-22. 